\title{
ASSESSING THE ENGLISH LANGUAGE PROFICIENCY OF RURAL STUDENTS FOR BETTER EMPLOYMENT OPPORTUNITIES
}

\author{
Dr. Madhumathi Pasupathi \\ Assistant Professor, Department of Humanities and Social Sciences, NIT Warangal, India \\ ORCID ID [0000-0001-9424-8233]
}

\begin{abstract}
Communication skill is one of the important generic skills essential for student's employment. After globalisation, communication skills are given importance due to varied business demands. Especially for students pursuing arts, science and commerce, the ability to communicate effectively is the most sought-after requirement during interviews and for seeking jobs. Thus, this study assess the communication skills of the rural students using a standardized English proficiency test and analyse their skill gaps in achieving English communicative competence based on their performances to the sub-skills of listening, speaking, reading and writing. The review of literature reports that there is lack of appropriate training in English communication skills for rural students studying in Arts and Science colleges. The findings of this study also reveals that the competency levels of the rural students are mostly low and in some cases it is reaching low intermediate level of ACTFL benchmarks.
\end{abstract}

Key words: Communication skills, Rural, English, Language Education.

Cite this Article: Madhumathi Pasupathi, Assessing the English Language Proficiency of Rural Students for Better Employment Opportunities, International Journal of Management, 11(12), 2020, pp 81-86.

http://iaeme.com/Home/issue/IJM?Volume=11\&Issue=12

\section{INTRODUCTION}

Communication skills are vital for fruitful future career of a student. After globalisation, communication skills are given more importance due to varied business demands. Thereby, the ability to communicate effectively is the most sought after requirement during interviews and for seeking jobs. According to the recent survey Telangana ranks third among other states in terms of unemployment in India (Raju, C., 2019). Most of the students from rural background studying in Arts and Science colleges are not placed in jobs immediately after completion of their degree (Hassall, T, 2013; Korra, V., 2016). Nevertheless, there are number of job opportunities available for graduates in various job sectors like marketing, HR, 
management, receptionist, tourist guide and so on. Even then the employment ratio of students completing graduation is less in Telangana (Sangeeta Kamat, 2011; P. H. Mohammad, 2020). Therefore, it is necessary for the students to improve their communication skills to get employment. Indian Human Development Survey (2005) data accounts that in Hyderabad, English speaking skills is associated with $44.2 \%$ higher earnings and speaking a little English is associated with $36.2 \%$ higher earnings, higher when compared to corresponding national average (Azam \& Et.al,2013; Warschauer, M, 2000; Zaharim, A, 2009). Thus, the study suggests possible measures to appropriately assess the proficiency levels of the students from rural background studying in arts and science colleges of Telangana. It also benchmarks the proficiency levels of the students on par with global standards. This enables the facilitators to understand the existing skill gaps among students and device appropriate intervention so that their communication improves for better employability as per the global job requirements.

\section{REVIEW OF LITERATURE}

Stevens (2005) conveyed that employers avoid recruiting low language proficiency students believing that they may not communicate efficiently with the clients and satisfy their expectations. This shows that there is a gap between the expectations of industries and what the universities offer to the students. Most of the studies conducted on communication reports that the most essential skills that every graduate must possess to get job and to work efficiently in the business environment is oral communication skills (Kassim and Ali, 2010; Crosling, G., \& Ward, I., 2002).

According to Azam, Chin and Prakash (2013) the ability to speak fluently in English yields $32 \%$ higher earnings for the student, which is four times higher earnings when compared to the average return to an additional year of schooling. However, the study reports that the investment to attain spoken English skills is low. Indian Human Development Survey (2005) data accounts that in Hyderabad, English speaking skills is associated with $44.2 \%$ higher earnings and speaking a little English is associated with $36.2 \%$ higher earnings, which is higher when compared to not speaking English group and the corresponding national average (Azam and Et.al, 2013). The curriculum needs to be more relevant to industry demands, because this will help to enhance human-capital development in the country (Datuk Seri Abdullah Ahmad Badawi, The Star, May 21, 2007, Saidalvi, A. B., 2009, Lamb, M; 2012).

\section{FRAMEWORK AND METHODS PROPOSED FOR RESEARCH}

The researcher has chosen diagnostic design for the purpose of this study. The diagnostic test is designed by referring to the American Council on Teaching of Foreign Languages (ACTFL) proficiency guidelines in order to benchmark the proficiency levels of the students. A standardized EPT from Cambridge English is used for assessing the proficiency of the students. The components of communication skills such as aural and oral communication, basic written communication, vocabulary and interpretive skills was tested. The students performances for the sub-skills of LSRW was tested in line with their capabilities for effective speaking and Listening, basic knowledge in official correspondence, summarising the texts, identifying the main ideas, details and specific information, paraphrasing, using coherence and cohesion devices in writing, giving feedbacks, asking questions, comprehension, Grammar and vocabulary use (Robles, M. M, 2012). A questionnaire was set to gather the background details of the students. The responses of the students for the willingness to learn English communication skills is also recorded. 


\subsection{Sampling frame and Technique}

The universe of the study constitutes rural students studying at Arts and Science colleges in Telangana. Around 2,840 students from different Arts and Sciences colleges located near rural areas in select district of Telangana have participated in this test. Background details was collected from all these students after explaining the details of the study. The standardized proficiency test was conducted to all these students. Prior approval is taken for using the test for data collection from Cambridge English and for conducting the data collection from concerned government authorities of Telangana.

\section{RESULTS}

Table 1 English Test Performance \% of the rural students

\begin{tabular}{|l|c|}
\hline \multicolumn{1}{|c|}{ Skills } & ET Performance Percentage \\
\hline Listening & 19.25 \\
\hline Speaking & 15.54 \\
\hline Reading & 26.68 \\
\hline Writing & 10.79 \\
\hline Vocabulary & 40.12 \\
\hline grammar & 23.27 \\
\hline Overall & 27.61 \\
\hline
\end{tabular}

The overall results of the English proficiency test reports that only $27 \%$ of students have performed well and reaching intermediate level of the ACTFL proficiency levels. Around $73 \%$ of students are in low proficiency level. The intermediate level are further divided in to intermediate high, mid and Low. The results indicate that less than $6 \%$ of the student reaches intermediate high level of ACTFL standards.

These rural students have performed moderately well $(40.12 \%)$ for vocabulary items of the test, however words that are not regularly in use are answered mostly wrong (18.9\%). Around $23.27 \%$ of the students have answered correctly for questions testing grammar. Most of the students do not have problems with concord (48\%) but they have performed poorly for questions testing tenses $(7.2 \%)$, sentence pattern $(10.45 \%)$, reported speech $(30.3 \%)$ and voice $(3.30 \%)$.

The reading comprehension performance of the students are higher $(26.68 \%)$ than that of listening comprehension (19.25\%). In comprehension, many students have answered for questions involving direct information $(30.01 \%)$ but they have problem in identifying the main idea $(12.37 \%)$ of the passage and for questions involving interpretations $(15.8 \%)$. They have performed moderately for questions involving inferences $(22.97 \%)$. The students have performed low for the sub-skills of speaking (15.54\%) and writing (10.79\%). contrastingly, for questions involving one word or one sentence responses most of the students $(76.40 \%)$ have replied well. More than $90 \%$ of the students responded positively for the willingness to learn English communication skills. Understanding the performance percentage of these students for individual skills is essential to design a course with appropriate scaffolding which may make them eligible for the jobs available in sectors globally.

\section{DISCUSSIONS}

The overall performances of the rural students for the standardized test is at low proficiency level and only less students have reached the excepted intermediate level proficiency in English as per ACTFL proficiency guidelines. Thus, explains the need for remedial classes for these rural students entering higher education. Benchmarking the proficiency of these students 
on par with global standards are necessary to identify their position on a global scale. Hence the study has evaluated the proficiency levels of these rural students and benchmarked their standards in comparison to the ACTFL proficiency standards.

Thus analysis reports that these rural students seem to have acquired commonly used English academic vocabulary. Due to less practice they mostly produce utterances using the familiar words instead of orderly arrangement of words in the sentences. This ensures that around $50 \%$ of these rural students have basic proficiency in English that enabled them to provide better responses in familiar topics during face to face conversations. However, they have issues in stating their views as a structured sentences. They feel embarrassed to make conversations in some complicated situations even though they are familiar with the topics. Moreover, they have less exposure to listening to native speakers of English. They find it difficult to infer or interpret meaning from an unfamiliar context. Thus, the analysis on the performance of the rural students for the sub-skills of the LSRW skills evidently proves that these students have acquired receptive skills of English better than that of productive skills. Thus, they need intense practice in using their receptive skills into productive form which is lacking in the present academic backgrounds of the rural students studying in Arts and Science colleges of Telangana. Thus, the study extends further scope for research in analyzing the proficiency levels of students from various states of India (Talif, R., \& Edwin, M, 2017).

Moreover, these students lack presentation skills which indicate the need for training in communication skills emphasizing on oral and written official communications. The in-depth analysis of the students' performances to the sub-skills of LSRW indicates that the students have performed better for questions involving interpretive skills when compared to skills involving presentation. They cannot connect sentences in order to describe experiences, events and opinions. In addition, they struggle to implement skills such as summarizing a text or discussing on the text in the target language.

The possible solution for enhancing the LSRW skills is to improve the expose the students to more practical sessions (Louhiala-S \& et. al, 2011). Teaching LSRW skills using the task based approach may increase the practice sessions in the classrooms. Overall, training the students in language laboratories will improve the scope or practicing English communication skills. However, there are no such facilities such as language laboratory in the arts and sciences colleges of Telangana. Therefore, theory hours can be replaced with communication activities which may activate their receptive skills and thus sequentially improve the productive skills of the rural students. Hence, the study emphasizes on the revision of English language curriculum as relevant to the requirement of local job sectors and also to bridge the expectations of the global job sectors (Nunan, D., 2003).

The responses of the students for the willingness to learn English communication skills reveals that the students wish to improve their communication skills, therefore profiling for individual students learning is necessary for tracking their performances and to implement remedial measures or intervention based on the individual student need. By benchmarking the proficiency levels of these rural students, the study gives the guideline for improving the communication skills of the students that in turn will positively influence the employment ratio of these rural students studying in arts and science colleges of Telangana.

\section{CONCLUSION}

Communication skills are essential for any graduate to attain a job and to work effectively in job environment. However, students from rural areas have low proficiency in English which may directly affect their recruitment to any job positions. Thus, improving the quality of English language education in arts and science colleges will naturally improve the employment ratio of the rural students studying in arts and science colleges. Incorporating 
practice classes within the curriculum is essential for improving the competence of the students in LSRW skills. Since the students have receptive skills, practical sessions may improve their productive skills in English communication. Thus, benchmarking the students' proficiency is essential for planning and overcoming the challenges encountered by the rural students in acquiring communication skills.

\section{ACKNOWLEDGMENT}

This study is funded by IMPRESS, Indian Council of Social Science Research, Delhi.

Bionote of the Author: Madhumathi Pasupathi is working as Assistant professor in the Department of Humanities and Social Sciences at NIT Warangal. She has contributed and owns a copyright for two psychological tools related to ELT indexed by American Psychological Association in APA PsycTESTS Database. She is a creative writer as well and has published a short story collection.

\section{REFERENCES}

[1] ACTFL, J. (2012). ACTFL proficiency guidelines 2012.

[2] Azam, M., Chin, A., \& Prakash, N. (2013). The returns to English-language skills in India. Economic Development and Cultural Change, 61(2), 335-367.

[3] Hassall, T., Arquero, J. L., Joyce, J., \& Gonzalez, J. M. (2013). Communication apprehension and communication self-efficacy in accounting students. Asian Review of Accounting.

[4] Kassim, H., and Ali, F. English communicative events and skills needed at the workplace: feedback from the industry. English for Specific Purposes; 2010, 29, 168-182.

[5] Korra, V. (2016). Seasonal Migration and Rural Markets: Empirical Evidence from Telangana, India. Social Science Asia, 2(1), 60-76.

[6] Lamb, M. (2012). A self system perspective on young adolescents' motivation to learn English in urban and rural settings. Language learning, 62(4), 997-1023.

[7] Liskin-Gasparro, J. E. (2003). The ACTFL proficiency guidelines and the oral proficiency interview: A brief history and analysis of their survival. Foreign Language Annals, 36(4), 483490.

[8] Louhiala-Salminen, L., \& Kankaanranta, A. (2011). Professional communication in a global business context: The notion of global communicative competence. IEEE Transactions on professional communication, 54(3), 244-262.

[9] Nunan, D. (2003). The impact of English as a global language on educational policies and practices in the Asia-Pacific Region. TESOL quarterly, 37(4), 589-613.

[10] Raju, C. (2019). Understanding Development of Two States; a Study of the Bifurcation of Andhra Pradesh. GNLU JL Dev. \& Pol., 9, 126.

[11] Robles, M. M. (2012). Executive perceptions of the top 10 soft skills needed in today's workplace. Business communication quarterly, 75(4), 453-465.

[12] P. H. Mohammad (2020) Minorities and culture of learning: an anthropological study of the Muslim community in Telangana state in India, Asian Ethnicity, DOI: 1080/14631369.2020.1797474

[13] Saidalvi, A. B. (2009) Oral communication skills in English: Matching the skills with the need and demand of the industry. Uniersiti Teknologi Malaysia Johor Bahru.

[14] Sangeeta Kamat (2011) Neoliberalism, urbanism and the education economy: producing Hyderabad as a 'global city', Discourse: Studies in the Cultural Politics of Education, 32:2, 187-202 
Assessing the English Language Proficiency of Rural Students for Better Employment Opportunities

[15] Stevens, B. What Communication Skills Do Employers Want? Silicon Valley Recruiters Respond. Journal of Employment Counseling; 2005, 42(1).

[16] Subramanian, T.S.R (2016). Report of the committee for Evolution of the New Education Policy. New Delhi: Government of India.

[17] Talif, R., \& Edwin, M. (2017). A Comparative Study of the Achievement and the Proficiency Levels in English as a Second Language among Learners in Selected Rural and Urban Schools:ois] in Peninsular Malaysia. The English Teacher, 10.

[18] Warschauer, M. (2000). The changing global economy and the future of English teaching. Tesol Quarterly, 34(3), 511-535.

[19] Zaharim, A., Yusoff, Y. M., Omar, M. Z., Mohamed, A., Muhamad, N., \& Mustapha, R. (2009). Employers perception towards engineering employability skills in Asia. WSEAS Transactions on Advances in Engineering education, 6(9), 306-15. 